Ann. Biol. anim. Bioch. Biophys., 1978, 18 (3), 735-746.

\title{
The fate and role of macromolecules synthesized during mammalian oocyte meiotic maturation. I. Autoradiographic topography of newly synthesized RNA and protein in the germinal vesicle of the pig and rabbit
}

\author{
par J. MOTLIK, V. KOPEČNY, J. PIVKO* \\ Czechoslovak Academy of Sciences, \\ Institute of Animal Physiology and Genefics, \\ Department of Genetics, 27721 Libèchov \\ * Institute of Animal Production, \\ 94992 Nitra, Czechoslovakia
}

Summary. Pig and rabbit oocytes were cytoautoradiographically checked for their synthetic activities during meiotic maturation. Tritiated uridine and lysine or ${ }^{35}$ S-methionine were introduced into the culture medium in which the oocytes were maintained either immediately at the beginning of the germinal vesicle breakdown in vitro or after reaching a more advanced stage of this process in vitro or in vivo. Some oocytes were maintained thereafter in a cold medium to trace the metabolism of the labelled protein.

In addition to uridine $-{ }^{3} \mathrm{H}$ incorporation into the nucleolus and nucleoplasm, during pig oocyte maturation it was found that an intensive RNA synthesis site appeared in association with condensing chromocentres of the GV II. A considerable proportion of oocytes from slaughterhouse material did not show intensive GV activity in RNA synthesis during maturation in vitro.

In the pig and rabbit oocyte it was shown that the newly synthesized ${ }^{3} \mathrm{H}$-lysine-labelled protein accumulated to a high degree in the GV and in the nucleolus. The labelled protein accumulated in the GV up to the stage of GV IV (pig) and persisted during the chase period in the ooplasm ; it was found to be associated with chromosomes of metaphase I (pig) or metaphase II (rabbit) of the meiotic division. The process of protein accumulation in the GV was not influenced by meiotic arrest during oocyte culture in autologous follicular fluid.

A similar accumulation of the label in the GV was detected in oocytes which were cultured in a medium enriched by ${ }^{35} \mathrm{~S}$-methionine.

In some oocytes the labelled protein failed to accumulate in the nucleolar area during maturation in vitro.

\section{Introduction.}

An understanding of the sub-cellular events occurring during fertilization presupposes among other things a knowledge of the origin and role of different long-life mole:ules formed at different times before fertilization during differentiation of both gametes. In the oocyte, a significant mission is attributed even to those macromolecules which are synthesized during the very last period before ovulation, which is 
called meiotic maturation and includes a process of germinal vesicle breakdown (GVB) and 1st polar body emission. According to cytophysiological evidence, a factor responsible for the activation of the sperm genome is synthesized in the rabbit oocyte during this period (Thibaud and Gérard, 1970). A similar situation has been detected in other mammals so far studied : mouse (Iwamatsu and Chang, 1972), pig (Motlík and Fulka, 1974a), man (Soupart, 1975) and cattle (Thibault et al., 1975).

Only recently has it been recognized that the final stages of the development of the mouse follicular oocyle are also a period when very intensive synthesis of RNA and protein takes place (Bloom and Mukherjee, 1972 ; Rodman and Bachvarova, 1976 ; Wassarman and Letourneau, 1976a, b). A conspicuous localization of newly synthesized products has been reported in the germinal vesicle (GV).

In this paper we report an autoradiographic study of RNA and protein synthesis in pig and rabbit oocytes matured in vitro, with the main emphasis on topography and time sequence of RNA and protein metabolism in the GV. Our further research in this area will cover the fate of the labelled material after GVB in the ooplasm, especially during fertilization.

\section{Material and methods.}

Oocyte source and culture conditions. - Pig oocyies were obtained either from slaughterhouse material (mostly Large White breed) (Motlik, 1972) or from superovulated gilts of the Minnesota and Göttingen miniature strains (Motlík and Fulka, 1976). Oocytes with cumulus cells were cultivated in a medium (Motlik and Fulka, 1974a) enriched with tritium-labelled precursors of RNA or protein, for various periods of time (table 1 and 2), with or without a following chase. In one experiment, the culture medium was replaced with freshly obtained, centrifuged pig follicular fluid.

Rabbit oocytes were obtained from preovulatory follicles of superovulated does 12 hrs after the last injection of FSH (Folicotropin, Spofa). They were put in the medium (Motlík and Fulka, 1974b) enriched by tritiated lysine immediately after the perforation of the follicles by needle.

\section{TABLE I}

Autoradiographic topography of RNA synthesized in pig oocyfes

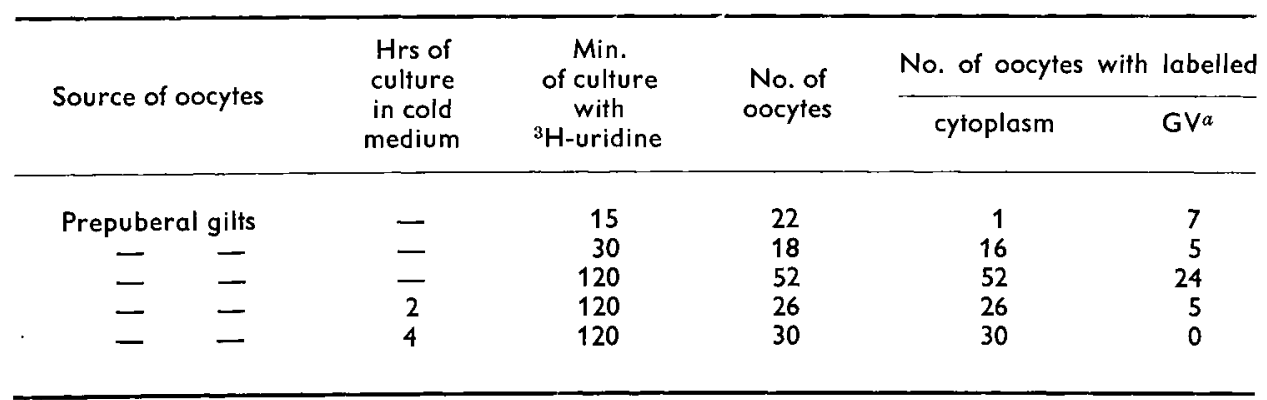

a Labelling more intense than the surrounding cytoplasm. 
RNA synthesis. - Uridine-5-3 $\mathrm{H}$ of specific activity ranging from 13.7 to $24.7 \mathrm{Ci}$ / mmol (UVVVR, Prague, Czechoslovakia) was introduced into the culture medium at a concentration of $50 \mu \mathrm{Ci} / \mathrm{ml}$. Pig ovarian oocytes were cultured in this medium for 15 , 30 or $120 \mathrm{~min}$. (table 1).

Protein synthesis. -- L-lysine-4.5-3 $\mathrm{H}$ (n) monohydrochloride (specific activity $250 \mathrm{mCi} / \mathrm{mmol}$, Amersham, UK) was added to the medium at a total concentration of $50 \mu \mathrm{Ci}$ per $\mathrm{ml}$. Pig and rabbit oocytes were cultured in this medium continuously for 2 , 3 or 5 hrs from the beginning of their maturation in vitro or after a period of culture in a cold medium (table 2). In some experiments (table 2) continuous labelling was followed by three washings in a cold medium and subsequent culture in the cold medium (chase) for 5 or 15 (pig) or 8 (rabbit) hrs.

TABLE 2

Autoradiographic topography of newly synthesized protein in pig and rabbit oocytes

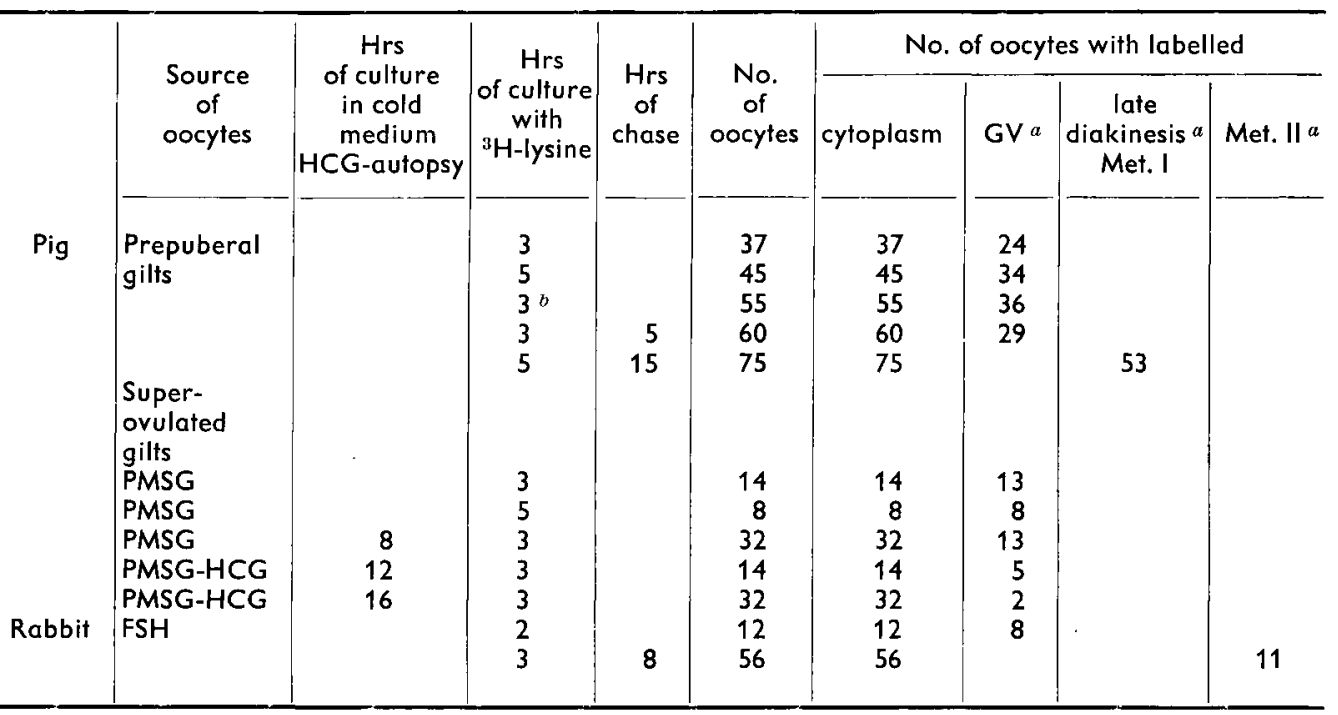

a Labelling more intense than the surrounding cytoplasm.

$b$ Oocytes were cultured in autologous follicular fluid enriched by ${ }^{3} \mathrm{H}$-lysine.

Oocytes from the superovulated gilts were removed after the times indicated in table 2 and cultured for $3 \mathrm{hrs}$ in the hot medium.

${ }^{35} \mathrm{~S}$-L-methionine (specific activity $128.8 \mathrm{mCi} / \mathrm{mmol}$ ) was used at a total concentration of $100 \mu \mathrm{Ci} / \mathrm{ml}$. The oocytes were cultured continuously in this medium for $3 \mathrm{hrs}$.

Cytological procedures. - The oocytes were prepared for autoradiography as Durcupan thick sections or as air-dried spreads. In the latter method, the ooplasm was more or less dispersed. For Durcupan sections pig oocytes were fixed with 2 p. 100 glutaraldehyde PBS, post-fixed in 1 p. 100 osmium tetroxide in PBS according to Szöllösi and Hunter (1973), embedded in Durcupan (Fluka), sectioned to about 0.1-0.5 $\mu \mathrm{m}$ and stretched on slides. 
For other preparations, the cumulus celles were removed and the zona pellucida dissolved in 0.15 p. 100 trypsine (Difco). Zona-free pig and rabbit oocytes were maintained for $10 \mathrm{mn}$ in a protein-rich medium and prepared as spreads in this medium on slides and air-dried. The slides were fixed for 20-24 hrs in neutral-phosphate buffered with 4 p. 100 formol at $4{ }^{\circ} \mathrm{C}$, rinsed for $2 \mathrm{hrs}$ in running tap water, extracted at about $2{ }^{\circ} \mathrm{C}$ for $5 \mathrm{mn}$ with $5 \mathrm{p} .100 \mathrm{TCA}$, rinsed for 90 to $120 \mathrm{mn}$ with tap water, extracted with alcohol-ether for $15 \mathrm{mn}$, washed in alcohol, and air-dried.

Both kinds of preparations were coated with nuclear liquid emulsion llford K. 5 and exposed for one month ( ${ }^{3} \mathrm{H}$-labelled precursors) or 6 days $\left({ }^{35} \mathrm{~S}\right)$ in a partial vacuum at $4^{\circ} \mathrm{C}$. After development, the Durcupan sections were stained with methylene blue after emulsion hardening with formaldehyde (4 p. 100), $\mathrm{pH} 7.1)$; the spreads were stained by 0.1 percent toluidine blue (Gurr) acetate-buffered to $\mathrm{pH}=4.0$. The autoradiograms were mounted with Clearmount (Gurr).

\section{Results.}

\section{RNA synthesis}

Continuous labelling for 2 hrs after the beginning of pig oocyte maturation in vitro resulted in very intensive (total blackening) labelling of cumulus and corona radiata cells, intensive labelling of the cytoplasm and nucleoplasm, and very intensive labelling, and often total blackening, of the nucleolar area and the small area of condensed chromatin (fig. 3) of the GV I. Intensive labelling of the GV II in some oocytes was observed at labelling intervals from 2 to $4 \mathrm{hrs}$ after the beginning of culture. In addition to the situation as already described for GV I, the areas of the chromocenters, known to occur in this stage (Motlík and Fulka, 1976), were intensively labelled

\section{PLATE ।}

Autoradiograms of oocytes cultured for various times after isolation from the ovary in a medium enriched with labelled precursors.

Nuclear liquid emulsion llford K. 5, exposure one month.

FIGS 1, 2. - Pig, ${ }^{3} \mathrm{H}-l y s i n e$, continuous labelling for $5 \mathrm{hrs}$, thick Durcupan section. The label is seen in the corona radiata and cumulus oophorus cells, the ooplasm, the GV and the nucleolus. There is very little label in the zona pellucida. Note the concentration of the label in the GV as compared to the ooplasm. There is a very high degree of labelling in the nucleolus (total blackening). In a somewhat thinner section (fig. 2), the granular nature of the labelling in the nucleolus is seen. GV between arrows. Approx. $400 X$.

FIGS 3, 4. - Pig, ${ }^{3} \mathrm{H}$-uridine, continuous labelling for 2 hrs., isolated GV in spread and air-dried preparafion. Fig. 3. GV I. Note very intense labelling in the nucleolar area and in the area of the chromatin (top). Note also intense nucleoplasm labelling. Fig. 4. - GV II. Heavy labelling is seen in the area of the chromocentres, in addition to labelling of similar intensity in the nucleolar (nu) area. Nucleoplasm is intensely labelled. Approx. $1500 \mathrm{X}$.

FIGS 5, 6. - Rabbit, ${ }^{3} \mathrm{H}-l y s i n e$, continuous labelling for 2 hrs., air-dried isolated GV. Note high accumulation of labelled protein in the GV, very intense labelling in the nucleolar area (fig. 5), and the association of the labelled material with the condensing bivalents of late dictyate (fig. 6). Approx. $1500 X$. 
(fig. 4). In many oocytes, on the other hand, GV labelling was not more intense than that of the surrounding cytoplasma (table 1).

After a short pulse $(15 \mathrm{mn})$ the cytoplasm was completely devoid of labelling. In one-third of the oocytes some silver grains were observed over nucleus and nucleolus. After a $30 \mathrm{mn}$. pulse the ooplasm was slightly labelled in most oocytes. A small number of them, however, showed a higher concentration of grains over the GV. The cumulus cells were intensively labelled in both short pulses.

\section{Protein synthesis}

\section{1) ${ }^{3} \mathrm{H}$-lysine incorporation}

a) Continuous labelling from the beginning of in vitro meiotic maturation.

- Pig.

Oocytes from superovulated gilts were evaluated for the distribution of newlyformed protein as Durcupan sections. After 3 or $5 \mathrm{hrs}$ of culture in the hot medium, the cytoplasm of all oocytes was distinctly labelled and the concentration of the grains overlying the GV was two to three times higher than that over the cytoplasm (fig. 1). In 85 p. 100 of oocytes the nucleolar region was more intensely labelled than the nucleoplasm (figs. 1 and 2).

Oocytes from tertiary follicles of immature gilts were treated similarly, but evaluated as air-dried spreads. Cytoplasmic labelling was again detected and the germinal vesicle was labelled to a higher degree in 65 p. 100 ( 3 hrs hot medium) or 75 p. 100 (5 hrs hot medium) of oocytes. On the other hand, great differences were detected in nucleolar labelling. In 50 p. 100 of the oocytes the nucleolar area was labelled less than the surrounding nucleoplasm or unlabelled (fig. 13). 35 p. 100 of the GV's were labelled envenly and only 15 p. 100 of the nucleoli were labelled more intensively than the nucleoplasm, as in superovulated gilts.

\section{PLATE II}

Autoradiograms of spread, air-dried oocytes. Ilford K.5, exposure one month.

FIG 7, 8. - Intense accumulation of the labelled protein in GV IV in a pig oocyle isolated 12 hrs. after HCG injection and cultured for $3 \mathrm{hrs}$. in ${ }^{3} \mathrm{H}-\mathrm{lysine}$ enriched medium. Focus on silver grains (fig. 7 ) or on condensed chromatin (fig. 8). Approx. $1500 \mathrm{X}$.

FIGS. 9-11. - Association of labelled protein with condensed chromosomes. Figs. 9, 10. - Pig metaphase I chromosomes are still labelled after continuous culture with ${ }^{3} \mathrm{H}$-lysine of isolated ovarian oocytes for 5 hrs. following 15 hrs. of chase in a cold medium. Fig. 9. - Isolated metaphase I chromosomes. Fig. 10. - Metaphase I chromosomes surrounded by ooplasm. A similar situation in the rabbit (fig. 11). 3 hrs. ${ }^{3} \mathrm{H}$-lysine, $8 \mathrm{hrs}$. chase. Metaphase II chromosomes are still more intensely labelled than the surrounding ooplasm. Approx. $1500 \mathrm{X}$.

FIG. 12. - Pig oocyte after continuous labelling for 3 hrs. in ${ }^{35} \mathrm{~S}$-methionine, air-dried. The labelled protein is selectively accumulated in GV. III ford K. 5, exposure 6 days. Approx. 1500 X.

FIG. 13. - In some pig oocytes (continuously labelled as indicated above), labelling in the nucleolar area was not defecfed. The condensing chromatin, on the other hand, was labelled in these oocytes (GV II). Approx. $1500 \mathrm{X}$. 
There was no marked difference in labelled protein accumulation and distribution in the oocytes cultured for $3 \mathrm{hrs}$ in autologous follicular fluid enriched only by tritiated lysine. According to our autoradiographic data, in more than $60 \mathrm{p} .100$ of the oocytes the GV showed a higher accumulation of labelled proteins than the ooplasm. Only about 10 p. 100 of oocytes showed the highest concentration above the nucleolar region. On the other hand, there was no absence of labelling of toluidine blue-stained structures.

\section{- Rabbit.}

Rabbit oocytes were cultured from the beginning of the meiotic maturation in vitro for $2 \mathrm{hrs}$ in the hot medium. There was very intensive labelling of the ooplasm but the difference in labelling due to the accumulation of proteins in the GV was not so marked as in pig oocytes. In the GV of some oocytes there was very intensive labelling of the nucleolar area with the adjacent chromatin (fig. 5) or a very high labelling of condensing bivalents in late dictyate stage (fig. 6).

b) Continuous labelling of pig oocytes in advanced stages of GV breadkown (GVBD).

To check the extreme stage of labelled protein accumulation during GVBD similar continuous labelling was used for oocytes which had already progressed to a more developed stage of this process either in vitro or in vivo after HCG injection. In those oocytes which were transferred to the hot medium after $8 \mathrm{hrs}$ of culture in a cold medium, the germinal vesicle (GV III and GVIV) was more intensely labelled than the surrounding nucleoplasm in 41 p. 100 of the oocytes. In other oocytes the labelling overlying the condensing bivalents was of the same intensity as in the cytoplasm. In oocytes isolated $12 \mathrm{hrs}$ after HCG injection and cultured for $3 \mathrm{hrs}$ in the hot medium the labelling in the GV was higher than tha: of the ooplasm in only onethird of the oocytes (figs. 7 and 8). In oocytes isolated $16 \mathrm{hrs}$ afier HCG labelling intensity in GV IV and in early diakinesis was the same as in the ooplasm. These observations indicate that the newly synthesized protein accumulated in the GV up to the stage of filamentous bivalents.

c) Continuous labelling from the beginning of in vitro meiotic maturation followed by a chase.

These experiments were devised to check the fate of the labelled protein during meiotic maturation. In pig oocyte culture, 3 or $5 \mathrm{hrs}$ of labelling in the hot medium was followed by a chase period of 5 or $15 \mathrm{hrs}$. After $5 \mathrm{hrs}$ of chase there was intense ooplasm labelling and stronger labelling in 50 p. 100 of oocytes with bivalents of GV III and GV IV. After $15 \mathrm{hrs}$ of chase there wais still intense lavelling of tile soplism and a clear association of the label with chromosomes in Icte diakinesis and metaphase I (figs. 9 and 10).

Rabbit oocytes were cultured in the hot medium for $3 \mathrm{hrs}$ with $\perp$ following chase of $8 \mathrm{hrs}$. After this treatment, the ooplasm was intensely label af and the label was found associated with the chromosomes $i 1$ metaphese in about $2 \%$ p. 100 of oocytes (fig. 11).

\section{2) ${ }^{35}$ S-L-methionine incortoration.}

In the autoradiograms of pig oocyter continuously cultured ir ihe medium enriched with ${ }^{35}$ S-L-methionine, intense iabelling was seen in the ooplasm and very intense 
labelling (total blackening) was detected in the cumulus cells. With this precursor too a similar selective accumulation of the label in the GV was observed, as referred to above. In 40 p. 100 of the oocytes, the concentration of the grains was two to three times higher than the concentration above the ooplasm (fig. 12); in a further 20 p. 100 of the oocytes the GV was slightly more strongly labelled than the ooplasm.

In the experiments using radioisotopes with sharply contrasting beta particle energy emission, we also noted similar overall proportions of oocytes exhibiting macromolecule metabolism. These results indicate that the shielding effect of the cytoplasm did not affect the results obtained after tritium disintegration registered by autoradiography.

\section{Discussion.}

During its development, the oocyte accumulates a variety of specific materials predestined to act as regulators of gene activity during early embryogenesis (Davidson, 1969 ; Brown and Dawid, 1968 ; Bachvarova, 1974). The present study tries to contribute to the understanding of a particular period of this process in the mammalian oocyte by an autoradiographic investigation of the metabolism of RNA and protein during the meiotic maturation of pig and rabbit oocytes.

Pig oocytes represent a very convenient material for topography and time sequence of newly synthesized macromolecule formation. In contrast to the situation in the mouse, the germinal vesicle breakdown in the pig is a comparatively long process extending over a period of about $20 \mathrm{hrs}$ which can be cytologically divided into at least four clearly defined stages (GV I to GVIV), marked by gradual condensation of chromatin and by nucleolus and nuclear membrane disappearance (Motlík and Fulka, 1976). Using cytoautoradiography after oocyte culture in a mediumi enriched with tritiated uridine, it is possible in this study to correlate to some degree these conspicuous changes in chromatin morphology with transcription activity in the maturing pig oocyte. The results indicate that, in addition to the high nucleolar activity in RNA synthesis and distinct labelling of the nucleoplasm, very intensive sites of uridine- ${ }^{3} \mathrm{H}$ incorporation appear during pig oocyte maturation in the areas of the condensing chromatin of the chromocentres in the GV II stage. The light microscopic methods used in the present study cannot offer data concerning the precise localization of the label within the complex structures of the condensing chromosomes nor the nature of the RNA synthesis visualized in the presently described conspicouus chromatin areas emerging during oocyfe maturation. It is known from the ultrastructural studies of chromosome condensation during meiotic maturation in the mouse (Calarco ef al., 1972 ; Chouinard, 1975) that the lengthy process of bivalent condensation includes transition from dictyate to lampbrush-like stage ; these are both known, from other types of cells, to be involved in transcriptive activity. Towards the end of the preovulatory stage in the mouse, the peripheral regions of the condensed portions of the bivalents consist of more loosely arranged chromatin fibrils (Chouinard, 1975). It may be presumed that, as detected in other cell types (see Fakan et al., 1976), these perichromatin nuclear regions of the condensed chromatin are the site of the synthesis of heterogeneous and pre-mRNA molecules on the perichromatin fibrils. Such 
mRNA's would probably be translated during the following stages of meiotic maturation or during the early stages of embryonic development. Similar work with the mouse (Rodman and Bachvarova, 1976) led to the conclusion that the synthesis of RNA in the mouse oocyte continues up to $2 \mathrm{hrs}$ before GVBD. It was also suggested by the same authors that the RNA's synthesized during the final stages of oocytes development are less stable than those synthesized earlier.

In our system of culture and uridine- ${ }^{3} \mathrm{H}$ radioactive labelling of oocytes collected from ovaries of slaughtered pre-pupertal gilts, a very high diversity in labelling intensity was observed in the GV and cytoplasm. In a considerable proportion of the oocytes, labelling stronger than in the ooplasm was not detected in the GV (table 1). These results may have been influenced by follicular cells known to be involved in the RNA synthesis of mouse oocytes in vitro and probably also in vivo (Wassarman and Letourneau, 1976a), and which may have been preserved in our preparations in varying amounts. The unequal source geometry of our spread preparations may also have influenced the autoradiographic detectability of the labelled GVs. Nevertheless, we suppose that this diversity of labelling revealed probable individual oocyte differences in the rate of RNA and also protein synthesis. These differences could reflect the initial stages of atresia of follicles from which oocytes were aspirated. Further research is planned in this direction.

Our results from the study of the localization of the newly synthesized lysine- ${ }^{3} \mathrm{H}$ labelled protein during meiotic maturation of pig and rabbit oocytes support the results already reported for the mouse oocyte and broadly discussed by Wassarman and Letourneau (1976b), i. e., newly-formed protein accumulation in the germinal vesicle and the persistance of the association of radioactive protein: with chromosomes during the later stages of meiosis. In addition to their findings we report conspicuous labelling in the nucleolar area, elevated labelling in the GV of pig oocytes arrested during maturation in vitro by culture in autologous follicular fluid, and the continuous accumulation of the protein in the maturing $G V$ up to the stage of filamentous bivalents of the GV IV. A major component of the protein accumulated in the pig and rabbit oocyte nucleus is probably also a lysine-rich histone, as was found in the mouse (Wassarman and Letourneau, 1976b). The same authors failed to defect the accumulation of ${ }^{3} \mathrm{H}$-tryptophan activity either in the GV or in the condensed chromosomes. Contrary to this we were able to detect an intensive increase of grains within the GV after oocyte culture in a medium enriched by ${ }^{35} \mathrm{~S}$-methionine, another amino acid which is known, like tryptophan, to be very low in the concentration in histones (Busch, 1965). We suppose that this observation may be interpreted as an indication of the storage of molecules other than the histone-type in the GV. The process of protein accumulation in the GV is a selective process. However no class of proteins other than histones was found to accumulate in the GV of amphibians at such a high rate as reported in the previous studies (Gurdon, 1974). RNA polymerase also probably accumulates in Rana pipiens GV's (Hollinger and Smith, 1976).

The physiological process of chromatin dispersal in the mammalian oocyte may be based on the action of some thiols which are supposed to directly reduce the disulfide cross-links in the chromatin (Gall and Ohsumi, 1976). The ${ }^{35} \mathrm{~S}$ from the ${ }^{35} \mathrm{~S}$-methionine in our experiments may have been easily transferred to the SH-groups of cysteine or glutathione (Lehninger, 1972). Glutathione is a very probable candidate 
for the main component of the oocyte reductase system (Gall and Ohsumi, 1976 ; see also Fahey et al., 1976). The labelling in the oocyte cytoplasm and the accumulation of the label in the GV may represent such a step as the buildup of a biochemical mechanism important in sperm head transformation. Marked qualitative changes in the synthesis of ${ }^{35} \mathrm{~S}$-methionine labelled proteins were detected in mouse (Schultz and Wassarman, 1977) and sheep oocytes (Warnes et al., 1977) after GV breakdown. These observations may correspond to the findings in mouse (Iwamatsu and Chang, 1972), rabbit (Thibault, 1972) and pig (Motlík and Fulka, 1974b), indicating that cytoplasm of oocytes obtained from the ovaries at metaphase I is fully matured as far as the male pronucleus formation in concerned.

The accumulation of the newly synthesized protein in the nucleoli of the oocytes during their maturation in vitro probably reveals those proteins which, after being synthesized in the cytoplasm, migrated to the nucleolus to interact with the ribosomal RNA precursors, thus forming a precursor complex (Busch and Smetana, 1970 ; Kufer and Rodgers, 1976 ; Fukuyama and Epstein, 1972). The lack of labelling in the nucleolar area of some oocytes, as observed in our material prepared by the spread technique, will be studied on a more reliable substrate for autoradiography. The nucleolus has a key role in the hormone-mediated stimulus of oocyte development, at least in a specific system (Lintern-Moore et al., 1976). It is tempting to speculate that nucleolar physiology may play a role in determining the reason for the inability of some oocytes to mature physiologically.

Reçu en novembre 1977.

Acceptè en février 1978.

Acknowledgments. - The authors would like to express thanks to Prof. K. Smetana for his kind interest in this work and namely for helpful discussion and review of the manuscript. We are also grateful to Mrs. Maria Dobrovodska and Mr. Václav Pech for the skillful technical assistance.

Résumé. Les activités de synthèse de l'ovocyte de truie et de lapine durant la maturation méiotique, ont été étudiées par cytoautoradiographie. De l'uridine et de la lysine tritiées ou de la méthionine ${ }^{35} \mathrm{~S}$ ont été introduites dans le milieu de culture, soit immédiatement au début de la rupture de la vésicule germinative (VG) in vitro, soit à des stades plus avancés soit in vivo, soit in vitro. Quelques-uns des ovocytes ont été maintenus ensuite dans un milieu froid, de manière à suivre l'évolution des ARNs et des protéines marqués.

Pendant la maturation de l'ovocyte de truie, en plus d'une incorporation de l'uridine dans le nucléole et le nucléoplasme, une synthèse intense d'ARN se produit au niveau des chromocentres en voie de condensation dans les VG au stade II. Une proportion très importante des ovocytes provenanf d'ovaires recueillis aux abattoirs ne montrent pas cette intense synthèse d'ARN in vitro.

Dans l'ovocyte des deux espèces, la plus grande partie des protéines nouvellement synthétisées et marquées à la lysine ${ }^{3} \mathrm{H}$, s'accumulent dans la VG et le nucléole. Ces protéines marquées accumulées dans la VG jusqu'au stade IV (truie) sont présentes dans le cytoplasme après la période de chasse. Elles sont associées aux chromosomes en métaphase I (truie) ou en métaphase II (lapine) des divisions méïotiques. L'accumulation dans la VG n'est pas modifiée si la reprise de la méiose est inhibée par la présence de liquide folliculaire.

Une accumulation de la radioactivité semblable est observée dans la VG après culture en présence de méthionine ${ }^{35} \mathrm{~S}$.

Dans quelques ovocytes les protéines marquées ne s'accumulent pas dans l'aire nucléolaire durant la maturation in vitro. 


\section{References}

BACHVAROVA R., 1974. Incorporation of tritiated adenosine into mouse ovum RNA. Dev. Biol., 40, 52-58.

BLOOM A. M., MUKHERJEE B. D., 1972. RNA synthesis in małuring oocytes. Exp. Cell Res., 74, 577. 582.

BROWN D. D., DAWID I., 1968. Specific gene amplification in oocytes. Science, 160, 272-280.

BUSCH H., 1965. Histones and other nuclear proteins. Acad. Press, New York-London.

BUSCH H., SMETANA K., 1970. The nucleolus, Acad. Press, New York-London.

CALARCO P. G., DONAHUE R. P., SZÖLLÖSI D., 1972. Germinal vesicle breakdown in the mouse oocyfe. J. Cell Sci., 10, 369-385.

CHOUINARD L. A., 1975. A light and electron-microscope study of the oocyte nucleus during development of the antral follicle in the prepubertal mouse. J. Cell Sci., 17, 589-615.

DAVIDSON E. H., 1969. Gene activity in early development. Acad. Press, New York-London.

FAHEY R. C., MIKOLAJCZYK S. D., MEIER G. P., EPEL D., CARROL E. J., 1976. The glutathione thiol-disulfide status in the sea urchin egg during fertilization and the first cell division cycle. Biochim. biophys. Acta. 437, 445-453.

FAKAN S., PUVION E., SPOHR G., 1976. Localization and characterization of newly synthesized nuclear RNA in isolated rate hepatocytes. Exp. Cell Res., 99, 155-164.

FUKUYAMA K., EPSTEIN W. L., 1972. Synthesis and turnover of protein(s) in nucleoli during epidermal keratinization. Exp. Cell Res., 57, 15-22.

GALL W. E., OHSUMI Y., 1976. Decondensation of sperm nuclei in vitro. Exp. Cell Res., 102, 349-358.

GURDON J. B., 1974. The control of gene expression in animal development. Clarendon Press, Oxford.

HOLLINGER T. G., SMITH L. D., 1976. Conservation of RNA polymerase during maturation of the Rana pipiens oocyte. Dev. Biol., 51, 86-97.

IWAMATSU T., CHANG M. C., 1972. Sperm penetration in vitro of mouse oocytes at various times during maturation. J. Reprod. Ferf., 31, 237-247.

KUTER D. J., RODGERS A., 1976. The protein composition of HeLa ribosomai subunits and nucleolar precursor particles. Exp. Cell Res., 102, 205-212.

LEHNINGER A. L., 1972. Biochemistry. The molecular basis of cell structure and function. Worth Pub., New York.

LINTERN-MOORE S., MOORE G. P. M., PANTELOURIS E. M., 1976. Abnormal nucleolar growth in the oocytes of athymic « nude " mice. Exp. Cell Res., 97, 430-432.

MOTLIK J., 1972. Cultivation of pig oocytes in vitro. Fol. Biol. (Praha), 18, 345-349.

MOTLIK J., FULKA J., 1974a. Fertilization of pig follicular oocytes cultivated in vitro. J. Reprod. Fert., 36, 235-237.

MOTLIK J., FULKA J., 1974b. Fertilization and development in vivo of rabbit oocytes cultivated in vitro. J. Reprod. Fert., 40, 183-186.

MOTLIK J., FULKA J., 1976. Breadkown of the germinal vesicle in pig oocytes in vivo and in vifro. J. Exp. Zool., 198, 155-162.

RODMAN T. C., BACHVAROVA R., 1976. RNA synthesis in preovulatory mouse oocytes. J. Cell Biol., 70, 251-257.

SCHULTZ R. M., WASSARMAN P. M., 1977. Specific changes in the pattern of protein synthesis during meiotic maturation of mammalian oocytes in vitro. Proc. nat. Acad. Sci. USA, 74, 538-541.

SOUPART P., 1975. In vitro maturation and fertilization of human oocyte, 81-93. In THIBAULT C., La fécondation. Masson, Paris,

SZÖLLÖSI D., HUNTER R. H. F., 1973. Ultrastructural aspects of fertilization in the domestic pig : sperin penetration and pronucleus formation. J. Anat., 116, 181-206.

THIBAULT C. G., 1972. Final stages of mammalian oocyte maturation, 397-411. In BIGGERS J. D., SCHUETZ A. W. Oogenesis. Univ. Park Press, Baltimore.

THIBAULT C., GERARD M., 1970. Facteur cytoplasmique nécessaire à la formation du pronucleus mâle cans l'ovocyte de lapine. C. R. Acad. Sci. Paris, sér. D, 270, 2025-2026. 
THIBAULT C., GERARD M., MÉNÉZZ Y., 1975. Acquisition par l'ovocyle de lapines et de veau du facteur de décondensation du noyau du spermatozoïde fécondant (MPGF). Ann. Biol. anim. Bioch. Biophys., 15, 705-714.

WARNES G. M., MOOR R. M., JOHNSON M. H., 1977. Changes in protein synthesis during maturation of sheep oocytes in vivo and in vitro. J. Reprod. Fert., 49, 331-335.

WASSARMAN P. M., LETOURNEAU G. E., 1976a. RNA synthesis in fullygrown mouse oocytes. Noture (London), 261, 73-74.

WASSARMAN P. M., LETOURNEAU G. E., 1976b. Meiotic maturation of mouse oocytes in vitro : association of newly synthesized proteins with condensing chromosomes. J. Cell Sci., 20, 549-468. 